$\xi=-1$

\title{
Drivers of Customer Loyalty towards Islamic Subsidiary Banks in the Northern States of Peninsular Malaysia
}

\author{
Maria Abdul Rahman ${ }^{1 *}$, Mona Fairuz Ramli \\ ${ }^{1}$ School of Business Management, Universiti Utara Malaysia, Malaysia \\ ${ }^{2}$ Islamic College University Perlis, Malaysia \\ *Corresponding author E-mail: maria@uum.edu.my
}

\begin{abstract}
It is undeniable that customer loyalty contributes to the sustainability and success of the banking industry. With the intense competition in the industry, banks are now trying to retain their customers with the aim to increase their revenues. As there are disagreements among the variables that influence customer loyalty, this study examined the relationships between perceived value, image, satisfaction and loyalty in an integrative model. Analysis was done on data collected from 139 bank customers in the northern states of Peninsular Malaysia using Partial Least Squares. The results of the study revealed that perceived value and bank image led customers to experience greater satisfaction, resulting in customers to be more loyal to their banks. The research outcome contributes to the body of knowledge by integrating the four variables into one model and by testing the model in the banking industry. The findings from this study may assist bank managers to formulate strategies to increase their revenues through customer loyalty.
\end{abstract}

Keywords: Islamic banking subsidiary; Customer loyalty; Image; Partial Least Squares; Perceived value.

\section{Introduction}

The advancement of technology and globalization has caused the banking industry, which is the backbone for the global trade and economic system, to face fierce competition. These banks are facing competitive challenges day by day to attract and retain existing customers since the products and services are complementary to each other [1]. The banking industry in Malaysia consists of Islamic banks, conventional banks, and conventional banks that offer Islamic banking products and services through its Islamic subsidiaries. With the homogeneous characteristics of banking products, banks are now faced with the challenge of retaining their existing customers. One study [2] indicated that some customers do not see any real difference between the Islamic banking products and their competitors, or with conventional banks. Competing in undifferentiated product market has caused banks to rely on the maintenance of long-term relationships and customer satisfaction [3]. Therefore, creating loyal customers occupies a central place in almost any organization, and loyal customers appear to be one of the key engines for any business to succeed in the coming years. While retaining the existing customers is cheaper than attracting new customers, banks should focus on strategies that can strengthen their loyal customer base. According to one report [4], only 28 percent of Malaysian banking customers are fully engaged to their primary banks. Fully engaged customers are more loyal and profitable than average customers. These customers provide banks an average net return rate of $+23 \%$. In other words, if a bank invested RM100 in a fully engaged customer, the return would be RM123. Therefore, it is important for the banks to increase the number of loyal customers by engaging them with service providers. To do this, customer satisfaction should be a concern to the banks as higher satisfaction will lead to customer loyalty [5]. Despite the dynamic development of the antecedents of satisfaction and customer loyalty, more studies need to be conducted to investigate the relationship among factors that influence these variables as the relationships have not been completely understood [6]. Thus, this study intended to examine the influence of perceived value and image on satisfaction and customer loyalty in the Islamic subsidiary banks in the northern region of Peninsular Malaysia. In the Islamic banking system, customer loyalty refers to the customers' motivation, commitment and support towards Islamic banking. It is apparent that a customer's positive response and support towards the Islamic banking system ensures the growth and long-run survivability of industry. One study [7] posited that an individual's faith and obligation towards religion instead of his/her needs fulfillment because of riba' prevention in Islam contributed to the customers' response. Islamic subsidiary banks were chosen as the research context because of its recent emergence in the market. According to the Financial Sector Blueprint 2011-2020, Bank Negara Malaysia is expecting Islamic banking to account for 40 percent of the market share by 2020 . As such, many conventional banks that previously offered Islamic windows had now transformed it into Islamic subsidiaries. The introduction of Islamic subsidiaries requires a new brand look for the staff, product innovations and even a logo to name a few, but in reality, these banks still operate like an Islamic window at the expense of the Islamic subsidiary [8]. Therefore, it is worth investigating the influence of perceived value and image on satisfaction and customer loyalty on Islamic subsidiary banks. 


\section{Literature Review}

\subsection{Customer Loyalty}

Without exception, loyalty has been recognized widely as an important factor for a business's success in the marketing discipline. Loyalty is an imprecise concept with diverse thoughts and definitions argued by prior researchers. There are three main conceptualizations of customer loyalty that have been discussed by researchers: behavioral loyalty, attitudinal loyalty and composite loyalty [9]. Earlier researchers studied loyalty in a behavioral perspective entailing repeat buying or behavioral frequency and relative volume of same-brand purchasing $([10,11])$. However, other researchers ([12-15]) criticized the behavioral approach of loyalty due to its flaws that made researchers unable to fully understand customer loyalty. The attitude-based approach was then evaluated by theorists $([12,14,16])$ in order to overcome the shortfalls. In an attitudinal approach, researchers believe that incessant brand purchasing shows the positive attitude of a customer towards a brand [17]. However, some $([13,15,18])$ argued that it is not an accurate depiction of reality, as a customer's positive attitude and commitment towards a particular brand may not always lead to repurchase; moreover, there is a lack of predicting power in the attitudinal approach towards understanding the actual purchase behavior of a customer. Researchers later agreed that combining both the behavioral and attitudinal loyalty perspectives can be useful for better understanding customer loyalty. Thus, the combination of both researchers led to the development of the composite loyalty approach to measure customer loyalty ([18-22]). In the banking sector, loyalty refers to repeated visits by a customer to a certain bank over a long duration of time [23]. Creating loyal customers occupies a central place in almost any organization, and loyal customers appear to be one of the key engines for a business to succeed in the coming years [24]. Furthermore, results of one study [25] showed that customer loyalty is a central factor to surge banks' profitability and reducing costs, as comparatively, serving existing customers is cheaper than attracting and facilitating new customers. Thus, due to the homogeneous nature of the banking products and services, the banking sector has to rely on long-term customers' preservation and customer loyalty is a serious concern [3]. One author [26] suggested that customer loyalty is more desirable as it is cheaper to retain current customers than to acquire new ones.

\subsection{Perceived Value}

Researchers considered customer perceived value as a trade-off between two parties, where one receives financial value and the second receives benefit by using a particular product or service [27]. A study [28] stated that for all marketing activities, customer perceived value is the fundamental basis, as greater perceived value contributes to stronger motivations for revisit. Therefore, higher perceived value means greater chances of a customer returning to purchase a particular product and service [29]. Based on another study [30], there are four dimensions to measure customers' perceived value of a product or service, which are perceived service benefit, perceived social value, perceived emotional value and perceived value for money. Perceived service benefit refers to the benefits received by customers during a trade-off with banks [31]. Perceived social value is the utility that emerged from the product's or service's ability to enhance social self-concept [30]. This value highlighted the impression of customers on others [32]. For example, in Muslim countries, the usage of Islamic banking products and services is socially acceptable and honourable, while the conventional alternative is not as per Islamic rules and principles. The third dimension, emotional value refers to a customer's feelings (e.g. delight, pleasure, enjoyment of the visual appeal, and reputation) that a product or service generates from the customer's consumption experience [30]. For example, users of Islamic banking products and services feel more comfortable and mentally relaxed because of their obedience to Islamic rules and regulations The last dimension, perceived value for money represents the economic value received by customers of Islamic banking products or services as compared to the monetary cost of the services. Studies established customer perceived value for money as significant in loyalty and decision-making ([33,34]). This study follows the multidimensional concept of perceived value. Its ability to overcome excessive concentration on economic utility had made this approach more popular than the traditional benefit-sacrifice approach [35]. By operationalizing perceived value into several components, validity problem can be overcome [36].

\subsection{Image}

The benefits resulted from the relationship with business partners and communicates the service provider's reputation in the market can be used to define image. Some researchers $([37,38])$ said it can be regarded as a customer's opinion towards a firm, which could be the product's brand or the associations the customers have with the firm and the services it offers. Image reflected by a firm has the capability to change customers' perception of the goods and services offered, relationship with the supplier, and customers' minds [39]. A firm's market position can be maintained through a favourable image [6]. Image connects the customers' memory with the service providers and it assists the customers in communicating their personal feelings about the service providers [5]. Therefore, image can be used as an intangible tool that can differentiate a service provider from its competitors. A good and well-known image has an influence on customers' perception of the firm's communication, and procedures and can be viewed as an asset to the firm [40]. If customers perceive a good image, they will repeat their purchase in the future [5]. In addition, if a customer believes that a firm has a positive image, he/she will easily forgive minor errors made by the firm [40].

\subsection{Satisfaction}

Customer satisfaction has been stated to be the most important construct that affects customer loyalty ([37,41,42]). Moreover, customer satisfaction is vital for any firm's success because market competition is a key for customer retention, which eventually increases loyalty and decreases the customer's intention to switch [43]. Satisfaction is described as the fulfilment that a customer feels after experiencing an interaction with a service provider [42]. In the banking sector, one researcher [23] defined customer satisfaction as the positive feelings gained by a customer when the overall level of services provided by the banks exceeded the customer's expectation. According to the service-profit-chain relationships, satisfied customers tend to be loyal and they can contribute to service providers' revenue and profitability [44].

\section{Conceptual Framework and Hypotheses Development}

The conceptual framework of this study is shown in Figure 1. Perceived value and image will influence customer satisfaction, and satisfaction will in turn affect customer loyalty. The greater the value of service as perceived by the customer, the greater the customer loyalty towards the Islamic subsidiary banks. Similarly, the stronger the image of the service provider as perceived by the customer, the greater the level of customer loyalty towards the service provider. This implies that providing a high value of service satisfies customers, and this satisfaction in turn positively affects customer loyalty. Likewise, a stronger image of the service provider as perceived by customers will positively affect their level of satisfaction, which resulted in customer loyalty. 


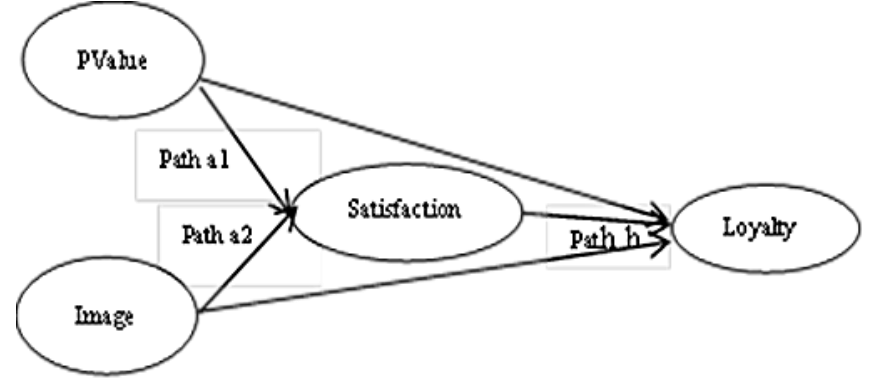

Fig. 1: Conceptual Framework

Superior customer value is one of the most main tools to sustain customer loyalty that leads to the success of a firm [45]. Customer values rely on various other attributes such as product knowledge, location of centre and financial resources [46]. Moreover, strategies development towards the creation of customer value is important in attracting new customers and to maintain a good relationship with them in order to gain customer loyalty. Thus, researchers considered that by creating a high level of customer value, there are chances of improving trust and commitment which lead to customer loyalty ([45,47]). According to one study [48], image has a significant influence on loyalty. One research [49] found that the greater the image of a firm, the greater the level of loyalty they will reflect. A study conducted in the hospitality industry showed that corporate image results in a positive influence on customer loyalty [37]. Another study [50] also found image to significantly influence satisfaction. In addition, prior research provided various empirical evidences regarding the significant impact of customer satisfaction towards loyalty in the service sector $([1,51])$. If the customer is pleased and happy with the products and services offerings, he/she tends to repurchase the products. In turn, if the customer continuously purchases products or services from the firm, loyalty has been achieved. Based on all the discussions, these hypotheses were developed:

H1: Perceived value significantly influences customer loyalty towards Islamic subsidiary banks.

$\mathrm{H} 2$ : Corporate image significantly influences customer loyalty towards Islamic subsidiary banks.

H3: Customer satisfaction significantly influences customer loyalty towards Islamic subsidiary banks.

H4: Perceived value significantly influences customer satisfaction towards Islamic subsidiary banks.

H5: Corporate image significantly influences customer satisfaction towards Islamic subsidiary banks.

\subsection{Customer Satisfaction as a Mediator}

Outcome of a few studies have shown positive relationships between perceived value, customer satisfaction and customer loyalty. For example, one study [52] found that perceived value influenced customer satisfaction and that customer satisfaction improved customer loyalty. Similarly, other studies $([53,54])$ found that perceived value was a predictor of customer satisfaction, and ultimately, customer satisfaction led to customer loyalty. In addition, another study [6] found that satisfaction is a mediator in the relationship between image and customer loyalty. Similarly, one researcher [55] declared corporate reputation predicts customer satisfaction and customer loyalty. Based on all the discussions, these hypotheses were developed:

H6a: Customer satisfaction mediates the relationship between perceived value and customer loyalty towards Islamic subsidiary banks.

H6b: Customer satisfaction mediates the relationship between image and customer loyalty towards Islamic subsidiary banks.

\section{Methodology}

This study was designed to follow the quantitative approach. The data was collected through a field survey. Questionnaires were distributed to customers of Islamic subsidiary banks in the northern region of Peninsular Malaysia. Besides collecting the demographic profiles of the respondents, the survey was used to assess the relationships of all the variables in this study. Customer loyalty was assessed using a seven-item scale adapted from a previous study [31]. Fourteen items drawn from another study [30] were used to measure perceived value. In addition, satisfaction was measured by adapting four items. Lastly, image was measured by four items adapted from two studies ([56,57]). A 7-point Likert scale ranging from 1 ="strongly disagree" to 7 = "strongly agree" was used to rate the four variables. Five conventional banks with Islamic subsidiaries in three towns namely Jitra, Alor Setar, and Kangar were selected as the sources of respondents. The mall intercept technique was used to assess the opinions of Islamic banks customers. Every fifth customer at each bank was approached to answer the questionnaire. Out of 250 questionnaires distributed, only 139 were returned and usable, providing a $55.6 \%$ response rate. This study employed the Partial-Least SquaresStructural Equation Modeling (PLS-SEM) to test the hypotheses developed earlier. PLS-SEM was chosen as it is well suited to analyze the small sample size of this study. The minimum sample requirement was determined through the 'ten times rule' [58]. In this study, the sample comprising 139 completed questionnaires was acceptable.

\section{Results and Conclusion}

\subsection{Response Rate and Demographic Profile}

Majority of the respondents of this study were male with the frequency level at 62.6 percent, while the female respondents made up the other 37.4 percent. Most of the respondents were in the age bracket of 20-29 years of age (69.8 percent), while only 2.2 percent were 60 years and above. Most of the respondents hold bachelor's degree (50.3 percent), while 18.2 percent completed secondary level education and 15.8 percent graduated with a diploma. Income wise, majority of the respondents earned between RM2,001 to RM4,000 per month (71.2 percent), followed by 10.8 percent of the respondents earning between RM4,001 to RM6,000 per month.

\subsection{Confirmatory Factor Analysis}

Confirmatory factor analysis (CFA) was conducted on all items adapted for this study. This study followed a two-step approach by assessing the measurement and structural models suggested by one source [59]. The Partial Least Squares (PLS) approach using Smart PLS Version 2.0 [60] was used to assess both the measurement and structural models.

\subsubsection{Assessment of Measurement Model}

Two steps were involved in assessing the CFA, namely the measurement model and structural model. The purpose of the measurement model was to assess and verify that all items used for each construct were both reliable and valid. In the measurement model, convergent validity, discriminant validity, and reliability were estimated. According to one researcher [61], convergent validity is assessed to ensure the items are measuring the same concept. Factor loadings, average variance extracted (AVE), composite reliability (CR), and Cronbach's alpha are the tools frequently used in assessing convergent validity. In order for the convergent validity to be established, it is recommended that the threshold values for the following are achieved: (a) factor loading for each item must exceed 0.50 [58], (b) AVE must be larger than 0.50 [62], and (c) the reliability score must exceed 0.70 [63]. 
Based on the assessment of factor loading among the constructs, an item of the corporate image was dropped, as the loading was below the recommended value of 0.50 . Table 1 shows that all loadings for the measurement items were greater than 0.60 and the AVE for all the constructs exceeded 0.50 . The results of the reliability scores (e.g. composite reliability and Cronbach alpha) for all the constructs exceeded 0.70. Therefore, all items showed adequate levels of convergent validity. One study [64] defined discriminant validity as the degree to which items measure different concepts. There are three ways of assessing discriminant validity, which include (1) examining whether items were loaded strongly on their own constructs in the model, or (2) comparing the square root of all AVE for each construct so that they exceeded all the inter-factor correlations between that and coefficients between constructs, or (3) comparing the AVE with the squared correlation estimates for all constructs. Table 2 compares the square root of the AVE of each construct with the correlation estimates. The results show that the square root of all AVE values for each construct exceeded all the inter-factor correlations between each construct, indicating an adequate level of discriminant validity. Therefore, it can be concluded that the measurement model is valid and reliable. The structural model can be further assessed to test the hypotheses.

\subsubsection{Assessment of Structural Model}

In conducting the CFA, the next step after assessing the measurement model is to evaluate the structural model using the bootstrapping procedure. The purpose of assessing the structural model was to test the research hypotheses. The results from the structural model in Table 3 indicated that perceived value exhibited a strong positive influence on customer loyalty $(\beta=0.461$, $t$-value $=4.418$, $\mathrm{p}<0.05)$ and satisfaction $(\beta=0.485, \mathrm{t}$-value $=5.866, \mathrm{p}<0.05)$. Image exhibited a positive influence on satisfaction $(\beta=0.375$, $t-$ value $=4.398, \mathrm{p}<0.05$ ), and its influence on customer loyalty was not significant $(\beta=0.041$, t-value $=0.405, \mathrm{p}<0.05)$. Satisfaction was also found to have a positive influence on customer loyalty with $\beta=0.041$, $t$-value $=0.405$ at $\mathrm{p}<0.05$. Except for $\mathrm{H} 2$, all other hypotheses (e.g. H1, H3, H4 and H5) were supported.

\subsubsection{Testing for the Mediating Effect of Satisfaction}

The procedure to test the mediating effect of satisfaction on the relationships between its determinants (e.g. perceived value and image) and customer loyalty followed the steps recommended by a past study [65]. To start with, without the interaction of a mediator (e.g. satisfaction) the path model was estimated. The results both revealed that both direct paths are statistically significant as shown in Table 4. Therefore, it is meaningful to include satisfaction as the mediator. The indirect paths should be significant in order to verify satisfaction to mediate the relationship between perceived value and customer loyalty, and between image and customer loyalty. To confirm the significance of these indirect paths, the sample table from bootstrapping was copied and pasted into MS Excel. From here, the standard errors were calculated in order to obtain the $t$ values of indirect paths. Using the bootstrapping procedure, an estimation of the indirect effects (a1b) and (a2b), standard errors, and both the bootstrap confidence interval at $95 \%$ confidence level was done. The values of paths a1, a2, and $\mathrm{b}$ represent the $\beta$ values or path coefficients of the relationships between perceived value and satisfaction, image and satisfaction, and satisfaction and customer loyalty, respectively (see Figure 1). In order to test the mediating effects, one researcher [66] required that each individual path a1,a2, and b to be significant. Based on Table 4, the bootstrap estimations of the indirect effect lie between 0.113 and 0.284 for H6, and between 0.102 and 0.205 for H7. It can be concluded that the indirect effects are significantly different from zero at $\mathrm{p}<0.05$ since zero is not in the $95 \%$ confidence intervals [65]. Thus, hypotheses H6a and H6b are supported, in which satisfaction mediates the relationship between perceived value and customer loyalty, and between image and customer loyalty.

Table 1: Results of Convergent Validity

\begin{tabular}{|c|c|c|c|c|c|}
\hline Constructs & Items & Loading & AVE & CR & $\begin{array}{c}\text { Cronbach } \\
\text { Alpha }\end{array}$ \\
\hline \multirow[t]{3}{*}{ Image } & IM 1 & 0.886 & 0.819 & 0.931 & 0.889 \\
\hline & IM2 & 0.927 & & & \\
\hline & IM3 & 0.901 & & & \\
\hline \multirow[t]{5}{*}{ Loyalty } & LO1 & 0.842 & 0.674 & 0.912 & 0.879 \\
\hline & $\mathrm{LO} 2$ & 0.896 & & & \\
\hline & LO3 & 0.824 & & & \\
\hline & $\mathrm{LO} 4$ & 0.737 & & & \\
\hline & LO5 & 0.798 & & & \\
\hline \multirow[t]{14}{*}{ Perceived Value } & PEV1 & 0.819 & 0.629 & 0.959 & 0.954 \\
\hline & PEV2 & 0.779 & & & \\
\hline & PEV3 & 0.773 & & & \\
\hline & PEV4 & 0.782 & & & \\
\hline & PQV1 & 0.832 & & & \\
\hline & PQV2 & 0.833 & & & \\
\hline & PQV3 & 0.852 & & & \\
\hline & PQV4 & 0.793 & & & \\
\hline & PSV1 & 0.775 & & & \\
\hline & PSV2 & 0.733 & & & \\
\hline & PSV3 & 0.695 & & & \\
\hline & PVFM1 & 0.799 & & & \\
\hline & PVFM2 & 0.817 & & & \\
\hline & PVFM3 & 0.806 & & & \\
\hline \multirow[t]{4}{*}{ Satisfaction } & ST1 & 0.881 & 0.818 & 0.947 & 0.926 \\
\hline & ST2 & 0.920 & & & \\
\hline & ST3 & 0.893 & & & \\
\hline & ST4 & 0.923 & & & \\
\hline
\end{tabular}

The results of this study provide us with the knowledge of the key predictors of consumer loyalty. It showed that perceived value and image were found to directly affected customer loyalty. In addition, satisfaction was found to mediate the relationships between perceived value and customer loyalty, and between image and customer loyalty. The findings of the study showed that increasing the values and image of the service caused higher customer satisfaction that led to a greater number of loyal customers. This result added to the knowledge by providing additional support to the findings in previous studies ([52-54]) and found that perceived value influenced customer satisfaction, and that customer satisfaction increased customer loyalty. Past research [6] found that satisfaction mediated the relationship between image and customer loyalty. The findings from this study suggest that if the Islamic subsidiary banks want to benefit from customer loyalty (e.g. increase in profitability and positive word of mouth) there is a need to focus on enhancing the values of products and services that the customer received compared to the competitors. Even though image was found to have significantly affect satisfaction and drives customer to be loyal to the banks, emphasis should be given on enhancing the value of the banks' products and services as its influence on satisfaction is stronger compared to the influence of image on satisfaction. It is vital for banks to focus on providing products and services that customer perceives to have high values. Besides that, banks should strengthen their image in their customers' minds and should always try to maintain or enhance it. Banks' 
strategic marketing plans should incorporate steps in improving the banks' image. The use of social media and word-of-mouth marketing should be considered by banks to improve their image. Continuous training of front-line employees should be conducted to maintain the employees' service culture. This will enhance the employees' knowledge and skill in handling the customers. Prompt action should be taken on customer complaints so that the customers will be satisfied and stay loyal with the banks. This action will also assist in strengthening the bank's image to the public. In conclusion, customer loyalty will develop if the formation of perceived value, image and satisfaction are well managed.

\section{Acknowledgement}

This research is fully funded by the Research Acculturation Grant Scheme (RAGS) from the Ministry of Higher Education Malaysia. (Project No.: 12698)

\begin{tabular}{|c|c|c|c|c|}
\hline \multicolumn{5}{|c|}{ Table 2: Results of Discriminant Validity } \\
\hline & Loyalty & Image & Perceived Value & S atisfaction \\
\hline Loyalty & 0.821 & & & \\
\hline Image & 0.714 & 0.905 & & \\
\hline $\begin{array}{c}\text { Perceived } \\
\text { Value }\end{array}$ & 0.813 & 0.789 & 0.793 & \\
\hline Satisfaction & 0.800 & 0.758 & 0.781 & 0.904 \\
\hline
\end{tabular}

Table 3: Results of Structural Model

\begin{tabular}{|c|c|c|c|c|c|}
\hline Hypothesis & Relationships & Std Beta & Std error & t- value & Decision \\
\hline H1 & $\begin{array}{c}\text { Perceived Value > } \\
\text { Customer Loyalty }\end{array}$ & 0.461 & 0.104 & 4.418 & Supported* \\
\hline H2 & $\begin{array}{c}\text { Image > Customer } \\
\text { Loyalty }\end{array}$ & 0.041 & 0.101 & 0.405 & Not supported \\
\hline H3 & $\begin{array}{c}\text { Satis faction > } \\
\text { Customer Loyalty }\end{array}$ & 0.409 & 0.089 & 4.601 & Supported* \\
\hline H4 & $\begin{array}{c}\text { Perceived Value > } \\
\text { Satis faction }\end{array}$ & 0.485 & 0.083 & 5.866 & Supported* \\
\hline H5 & Image > Satisfaction & 0.375 & 0.085 & 4.398 & Supported* \\
\hline
\end{tabular}

$\mathrm{p}<0.05$

Table 4: Results of Mediator Testing

\begin{tabular}{|c|c|c|c|c|c|c|c|c|c|}
\hline \multirow[b]{5}{*}{ Effects } & \multirow[b]{5}{*}{ Path } & & \multirow[b]{5}{*}{$\begin{array}{c}\text { Indirect } \\
\text { effect }\end{array}$} & \multirow[b]{5}{*}{ Std error } & & \multirow{4}{*}{\multicolumn{2}{|c|}{$\begin{array}{c}\text { Bootstrap } \\
\text { Confidence } \\
\text { Interval }\end{array}$}} & \multirow[b]{5}{*}{ Decision } \\
\hline & & \multirow[b]{4}{*}{$\begin{array}{c}\begin{array}{c}\text { Path } \\
\text { coeficient }\end{array} \\
\end{array}$} & & & & & & & \\
\hline & & & & & \multirow[b]{3}{*}{$\begin{array}{c}\text { Total } \\
\text { effects }\end{array}$} & \multirow[b]{3}{*}{ t-value } & & & \\
\hline & & & & & & & & & \\
\hline & & & & & & & $\begin{array}{l}95 \% \\
\text { Lower } \\
\text { Limit }\end{array}$ & $\begin{array}{l}95 \% \\
\text { Upper } \\
\text { Limit }\end{array}$ & \\
\hline $\begin{array}{l}\text { Direct without } \\
\text { mediator }\end{array}$ & PV to CL & 0.655 & \multicolumn{3}{|c|}{ Not applicable } & 7.511 & \multicolumn{2}{|c|}{ Not applicable } & Supported \\
\hline \multirow{3}{*}{$\begin{array}{l}\text { Indirect with } \\
\text { mediator }\end{array}$} & PV to CL & 0.469 & \multicolumn{2}{|c|}{ Not applicable } & \multirow{3}{*}{0.666} & \multirow{3}{*}{4.581} & \multirow{3}{*}{0.113} & \multirow{3}{*}{0.284} & \multirow{3}{*}{ Supported } \\
\hline & PV to CS & 0.479 & \multirow{2}{*}{0.197} & \multirow{2}{*}{0.043} & & & & & \\
\hline & CS to $C L$ & 0.411 & & & & & & & \\
\hline $\begin{array}{l}\text { Direct without } \\
\text { mediator }\end{array}$ & IM to $C L$ & 0.198 & \multicolumn{3}{|c|}{ Not applicable } & 2.099 & \multicolumn{2}{|c|}{ Not applicable } & Supported \\
\hline \multirow{3}{*}{$\begin{array}{l}\text { Indirect with } \\
\text { mediator }\end{array}$} & IM to CL & 0.042 & \multicolumn{2}{|c|}{ Not applicable } & \multirow{3}{*}{0.198} & \multirow{3}{*}{6.00} & \multirow{3}{*}{0.10} & \multirow{3}{*}{0.21} & \multirow{3}{*}{ Supported } \\
\hline & IM to CS & 0.38 & \multirow{2}{*}{0.156} & \multirow{2}{*}{0.026} & & & & & \\
\hline & $\mathrm{CS}$ to $\mathrm{CL}$ & 0.411 & & & & & & & \\
\hline
\end{tabular}

[9] Han H, Kim Y \& Kim EK, "Cognitive, affective, conative, and action loyalty: Testing the impact of inertia", International Journal of Hospitality Management, Vol.30, No.4, (2011), pp.1008-1019.

\section{References}

[1] Rizwan M, Yaseen G, Nawaz A \& Hussain L, "Incorporating Attitude towards Islamic Banking in an Integrated Service Quality, Satisfaction, Trust and Loyalty Model", International Journal of Accounting and Financial Reporting, Vol.4, No.2, (2014), pp.456-477.

[2] Al-Tamimi HAH, Lafi AS \& Uddin MH, "Bank Image in UAE: Comparing Islamic and conventional banks", Journal o Financial Services Marketing, Vol.14, No.3, (2009), pp.232-244.

[3] Hossain M \& Leo S, "Customer perception on service quality in retail banking in Middle East: the case of Qatar", International Journal of Islamic and Middle Eastern Finance and Management, Vol.2, No.4, (2009), pp.338-350.

[4] NA, (2016), Inside the Mind of the Malaysian Banking Customer Research-based insights into the future of Malaysian banking, from https://skrs.page.link/qL6j

[5] Tariq AN \& Moussaoui N, "The main antecedents of Custome Loyalty in Moroccan Banking Sector", International Journal of Business Management Science, Vol.2, No.2, (2009), pp.101-115.

[6] Keisidou E, Sarigiannidis L \& Maditinos DI, "Customer satisfaction, loyalty and financial performance: A holistic approach of the Greek banking sector", International Journal of Bank Marketing, Vol.31, No.4, (2013), pp.259-288.

[7] Asutay M, "Conceptualisation of the Second Best Solution in Overcoming the Social Failure of Islamic Banking and Finance: Examining the Overpowering of Homoislamicus by Homoeconomicus", IIUM Journal of Economics and Management, Vol.15, No.2, (2007), pp.167-196.

[8] Amin H, Explaining the terms Islamic window and Islamic subsidiary, The Borneo Post, (2017).
[10] Frank RE, "Is brand loyalty a useful basis for market segmentation?", Journal of Advertising Research, Vol.7, No.2, (1967), pp.27-33.

[11] McConnell JD, "The development of brand loyalty: an experimental study", Journal of Marketing Research, Vol.5, No.1, (1968), pp.13-19.

[12] Anderson RE \& Srinivasan SS, "E-satisfaction and e-loyalty: A contingency framework", Psychology \& Marketing, Vol.20, No.2, (2003), pp.123-138.

[13] Dick AS \& Basu K, "Customer loyalty: toward an integrated conceptual framework", Journal of The Academy Of Marketing Science, Vol.22, No.2, (1994), pp.99-113.

[14] Han H \& Back KJ, "Relationships among image congruence, consumption emotions, and customer loyalty in the lodging industry", Journal of Hospitality \& Tourism Research, Vol.32, No.4, (2008), pp.467-490.

[15] Oliver RL, "Whence consumer loyalty", Journal of Marketing, Vol.63, No.4, (1999), pp.33-44.

[16] Han H \& Ryu K, "The roles of the physical environment, price perception, and customer satisfaction in determining customer loyalty in the restaurant industry", Journal of Hospitality \& Tourism Research, Vol.33, No. 4, (2009), pp.487-510.

[17] Amine A, "Consumers' true brand loyalty: the central role of commitment", Journal of Strategic marketing, Vol.6, No.4, (1998), pp.305-319.

[18] Back KJ \& Parks SC, "A brand loyalty model involving cognitive, affective, and conative brand loyalty and customer satisfaction", Journal of Hospitality \& Tourism Research, Vol.27, No.4, (2003), pp.419-435.

[19] Oliver RL, Satisfaction: A Behavioral Perspective on the Consumer, New York: McGraw-Hill, (1997). 
[20] Kandampully J \& Suhartanto D, "The role of customer satisfaction and image in gaining customer loyalty in the hotel industry", Journal of Hospitality \& Leisure Marketing, Vol.10, No.1-2, (2003), pp.3-25.

[21] Evanschitzky H, Iyer GR, Plasmann H, Niessing J \& Meffert H "The relative strength of affective commitment in securing loyalty in service relationahips", Journal of Business Research, Vol.59, (2006), pp.1207-1213.

[22] Bandyopadhyay S \& Martell M, "Does attitudinal loyalty influence behavioral loyalty? A theoretical and empirical study", Journal of Retailing and Consumer Service, Vol.14, No.1, (2007), pp.35-44

[23] Ladhari R, Ladhari I \& Morales M, "Bank Service quality: comparing canadian and Tunisian customer perceptions", International Journal of Bank Marketing, Vol.29, No.3, (2011), pp.224-246.

[24] Reichheld FF, Teal T \& Smith DK, The loyalty effect (Vol. 1), Boston, MA: Harvard Business School Press, (1996).

[25] Hallowell R, "The relationships of customer satisfaction, customer loyalty, and profitability: an empirical study", International Journal of Service Industry Management, Vol.7, No.4, (1996), pp.27-42.

[26] Campo AM, Alves H \& Hernandez JM, (Eds.), Loyalty Measure ment in Tourism: A Theoretical Reflection, Physica -Verlag Haidelberg, (2013).

[27] Slater SF \& Narver JC, "Market orientation, customer value, and superior performance", Business Horizons, Vol.37, (1994), pp.2228.

[28] Holbrook M, The nature of customer value. In R. Oliver \& $r$. Rust (Eds.), Service quality: New directions in theory and practice. Thousand Oaks: Sage Publications, (1994).

[29] Hasan H, Kiong TP \& Ainuddin RA, "Effects of perceived value and trust on customer loyalty towards foreign Banks in Sabah Malaysia", Global Journal of Emerging Trends in e-Business,. Market ing and Consumer Psycholgy, (2014), pp.311-317.

[30] Sweeney J \& Soutar G, "Consumer perceived value: The development of multiple item scale", Journal of Retailing, Vol.77, No.2, (2001), pp.203-220.

[31] Zeithaml V, "Consumer Perception of Price, Quality, and Value: A Means-End Model and Synthesis of Evidence", Journal of Marketing, Vol.52, (1988), pp.2-22.

[32] Chen PT \& Hu HH, "The effect of relational benefits on perceived value in relation to customer loyalty: An empirical study in the Australian coffee outlets industry", International Journal of Hospitality Management, Vol.29, No.3, (2010), pp.405-412.

[33] McDougall GHG \& Leveque T, "Customer satisfaction with services: putting perceived value into equation", Journal of Service Marketing, Vol.14, No. 5, (2000), pp.392-410.

[34] Chen Z, Consumers' Value Perception of An e-Store and Its Impact on e-Store Loyalty Intention, Purdue University, West Lafayette, (2003).

[35] Sanchez J, Callarisa L, Rodriguez RM \& Moliner MA, "Perceived value of the purchase of a tourism product", Tourism Management, Vol.27, (2006), pp.394-409.

[36] Chen CF \& Chen FS, "Experience quality, perceived value, satisfaction and behavioral intentions for heritage tourists", Tourism Management, Vol.31, No.1, (2009), pp.1-7.

[37] Liat CB, Mansori S, Chuan GC \& Imrie BC, "Hotel Service Recovery and Service Quality: Influences of Corporate Image and Generational Differences in the Relationship between Customer Satisfaction and Loyalty", Journal of Global Marketing, Vol.30, No.1, (2017), pp.1-10

[38] Nguyen N \& LeBlanc G, "The mediating role of corporate image on consumers' retention decisions: an investigation in financial services", International Journal of Bank Marketing, Vol.16, No.2, (1998), pp.52-65.

[39] Kandampully J \& Suhartanto D, "Customer loyalty in the hotel industry: the role of customer satisfaction and image", International Journal of Contemporary Hospitality Management, Vol.12, No.6, (2000), pp.346-351.

[40] Kang GD \& James J, "Service quality dimensions: an examination of Gronroos's service quality model”, Managing Service Quality, Vol.14, No.4, (2004), pp.266-277.

[41] Hoq HZ \& Amin M, "The role of customer stisfaction to enhance loyalty", African Journal of Business Management, Vol.4, No.12, (2010), pp.2385-2392.

[42] Vesel P \& Zabkar V, "Managing customer loyalty through the mediating role of satisfaction in the DIY retail loyalty program", Jour nal of Retailing and Consumer Services, Vol.16, No.5, (2009), pp.396-406.

[43] Hennig-Thurau TH \& Klee A, "The impact of customer satisfaction and relationship quality on customer retention: a critical assessment and model development", Psychology \& Marketing, Vol.14, No.8, (1997), pp.737-765.

[44] Zeithaml VA, Bitner MJ \& Gremler DD, Service Marketing: Integrated customer Focus across Firm (7 ed.), New York: McGraw Hill Education, (2018)

[45] Wang Y, Hing PL, Chi R \& Yang Y, “An Integrated framework for customer value and customer-relationship-management performance: a customer-based perspective from China", Managing Service Quality, Vol.14, No.2/3, (2004), pp.169-182.

[46] Leroi-Werelds S, Streukens S, Brady MK \& Swinnen G, "Assessing the value of commonly used methods for measuring customer value: A multi-setting empirical study", Journal of the Academy of Marketing Science, Vol.42, No.4, (2014), pp.430-451.

[47] Zeithaml VA, Berry LL \& Parasuraman A, "The Behavioral Consequences of Service Quality”, Journal of Marketing, Vol.60, No. 2 (1996), pp.31-46.

[48] Akhter W, Abbasi AS, Ali I \& Afzal H, "Factors Affecting Customers Loyalty in Pakistan", African Journal of Business Management, Vol.5, No.4, (2011), pp.1167-1174.

[49] Fathollahzadeh M, Hashemi A \& Kahreh MS, "Designing a new model for determining customer value satisfaction and loyalty towards banking sector of Iran", European Jouranl of Economics, Finance and Administrative Sciences, Vol.28, No.1, (2011), pp.126138.

[50] Lai F, Griffin M \& Babin BJ, "How quality, value, image, and satisfaction create loyalty at a Chinese telecom", Journal of Business Research, Vol.62, No.10, (2009), pp.980-986.

[51] Liao KH, "Service Quality and Customer Satisfaction: Direct and Indirect Effects in loyalty in Taiwanese Internet banks", Social Behavior and Personality, Vol.39, No.8, (2012), pp.1127-1140.

[52] Yang Z \& Patterson RT, "Customer Perceived Value, Satisfaction, and Loyalty: The Role of Switching Costs", Psychology \& Market ing, Vol.21, No.10, (2004), pp.799-822.

[53] Cronin J, Brady M \& Hult T, "Assessing the effects of quality, value, and customer satisfaction on consumer behavioral intentions in service environments", Journal of Retailing, Vol.76, No.2, (2000), pp.193-218.

[54] Keshavarz Y \& Jamshidi D, "Service quality evaluation and the mediating role of perceived value and customer satisfaction in customer loyalty", International Journal of Tourism Cities, Vol.4, No.2, (2018), pp.220-244.

[55] Helm S, Eggert A \& Garnefeld I, Modeling the impact of corporate reputation on customer satisfaction and loyalty using Partial Least Squares, (2010), pp.515-534.

[56] Moliner MA, "Loyalty, perceived value and relationship quality in healthcare services", Journal of Service Management, Vol.20, No.1, (2009), pp.76-98.

[57] Lappiere J, "Customer perceived value in industrial contexts", Journal of Business and Industrial Marketing, Vol.15, No.2/3, (2000), pp.122-140.

[58] Hair JF, Ringle CM \& Sarstedt M, "PLS-SEM: Indeed A silver Bullet", Journal of Marketing Theory and Practice, Vol.19, No.2, (2011), pp.139-151.

[59] Anderson JC \& Gerbing DW, "Structural equation modeling in practice: A review and recommended two-step approach", Psychological Bulletin, Vol.103, (1988), pp.411-423.

[60] Ringle CM, Wende S \& Will A, Smart PLS, Hamburg, Germany, (2005).

[61] Ramayah T, Wai CL \& Boey CI, "Network collaboration and performance in the tourism sector", Serv Bus, Vol.5, (2011), pp.411428 .

[62] Barclay DW, Thompson R \& Higgins C, "The partial least squares (PLS) approach to causal modeling: personal computer adoption and use an illustration", Technology Studies: Special Issue on Research Methodology, Vol.2, No.2, (1995), pp.285-309.

[63] Nunnally JC \& Bernstein IH, Psychometric theory, New York: McGraw-Hill, (1994).

[64] Garver MS \& Mentzer JT, "Logistics Research Methods: Employing Structural Equation Modeling to Test for Construct Validity", Journal of Business Logistics, Vol.20, No.1, (1999), pp.33-57.

[65] Preacher KJ \& Hayes AF, "SPSS and SAS procedures for estimating indirect effects in simple mediation models", Behavior Research Methods, Instruments, \& Computers, Vol.36, No.4, (2004), pp.717-731.

[66] Hair JF, Hult GTM, Ringle CM \& Sarstedt M, A Primier on Partial Least Squares Structural Equation Modeling (PLS-SEM), Thousand Oaks, California, USA: Sage Publications, (2014). 